NASA/TM-2005-213337

\title{
Heat Rejection Concepts for Brayton Power Conversion Systems
}

John Siamidis

Analex Corporation, Brook Park, Ohio

Lee Mason, Duane Beach, and James Yuko

Glenn Research Center, Cleveland, Ohio 
Since its founding, NASA has been dedicated to the advancement of aeronautics and space science. The NASA Scientific and Technical Information (STI) Program Office plays a key part in helping NASA maintain this important role.

The NASA STI Program Office is operated by Langley Research Center, the Lead Center for NASA's scientific and technical information. The NASA STI Program Office provides access to the NASA STI Database, the largest collection of aeronautical and space science STI in the world. The Program Office is also NASA's institutional mechanism for disseminating the results of its research and development activities. These results are published by NASA in the NASA STI Report Series, which includes the following report types:

- $\quad$ TECHNICAL PUBLICATION. Reports of completed research or a major significant phase of research that present the results of NASA programs and include extensive data or theoretical analysis. Includes compilations of significant scientific and technical data and information deemed to be of continuing reference value. NASA's counterpart of peerreviewed formal professional papers but has less stringent limitations on manuscript length and extent of graphic presentations.

- TECHNICAL MEMORANDUM. Scientific and technical findings that are preliminary or of specialized interest, e.g., quick release reports, working papers, and bibliographies that contain minimal annotation. Does not contain extensive analysis.

- CONTRACTOR REPORT. Scientific and technical findings by NASA-sponsored contractors and grantees.
- CONFERENCE PUBLICATION. Collected papers from scientific and technical conferences, symposia, seminars, or other meetings sponsored or cosponsored by NASA.

- SPECIAL PUBLICATION. Scientific, technical, or historical information from NASA programs, projects, and missions, often concerned with subjects having substantial public interest.

- TECHNICAL TRANSLATION. Englishlanguage translations of foreign scientific and technical material pertinent to NASA's mission.

Specialized services that complement the STI Program Office's diverse offerings include creating custom thesauri, building customized databases, organizing and publishing research results ... even providing videos.

For more information about the NASA STI Program Office, see the following:

- Access the NASA STI Program Home Page at http://www.sti.nasa.gov

- E-mail your question via the Internet to help@sti.nasa.gov

- Fax your question to the NASA Access Help Desk at 301-621-0134

- Telephone the NASA Access Help Desk at 301-621-0390

- Write to:

NASA Access Help Desk

NASA Center for AeroSpace Information 7121 Standard Drive

Hanover, MD 21076 
NASA/TM-2005-213337

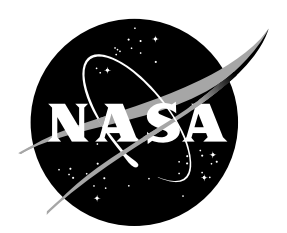

\section{Heat Rejection Concepts for Brayton Power Conversion Systems}

John Siamidis

Analex Corporation, Brook Park, Ohio

Lee Mason, Duane Beach, and James Yuko

Glenn Research Center, Cleveland, Ohio

Prepared for the

Second International Energy Conversion Engineering Conference

sponsored by the American Institute of Aeronautics and Astronautics

Providence, Rhode Island, August 16-19, 2004

National Aeronautics and

Space Administration

Glenn Research Center 


\section{Acknowledgments}

Project Prometheus, NASA's Nuclear Systems Program, supported the work described within this paper, in whole or part, as part of the program's technology development and evaluation activities.

This report contains preliminary

findings, subject to revision as analysis proceeds.

Trade names or manufacturers' names are used in this report for identification only. This usage does not constitute an official endorsement, either expressed or implied, by the National Aeronautics and Space Administration.

Available from

NASA Center for Aerospace Information 7121 Standard Drive

Hanover, MD 21076
National Technical Information Service 5285 Port Royal Road Springfield, VA 22100 


\title{
Heat Rejection Concepts for Brayton Power Conversion Systems
}

\author{
John Siamidis \\ Analex Corporation \\ Brook Park, Ohio 44142 \\ Lee Mason, Duane Beach, and James Yuko \\ National Aeronautics and Space Administration \\ Glenn Research Center \\ Cleveland, Ohio 44135
}

\begin{abstract}
This paper describes potential heat rejection design concepts for closed Brayton cycle (CBC) power conversion systems. Brayton conversion systems are currently under study by NASA for Nuclear Electric Propulsion (NEP) applications. The Heat Rejection Subsystem (HRS) must dissipate waste heat generated by the power conversion system due to inefficiencies in the thermal-to-electric conversion process. Space Brayton conversion system designs tend to optimize at efficiencies of about 20 to 25 percent with radiator temperatures in the 400 to $600 \mathrm{~K}$ range. A notional HRS was developed for a $100 \mathrm{kWe}$-class Brayton power system that uses a pumped sodium-potassium ( $\mathrm{NaK}$ ) heat transport loop coupled to a water heat pipe radiator. The radiator panels employ a sandwich construction consisting of regularly-spaced circular heat pipes contained within two composite facesheets. Heat transfer from the NaK fluid to the heat pipes is accomplished by inserting the evaporator sections into the NaK duct channel. The paper evaluates various design parameters including heat pipe diameter, heat pipe spacing, and facesheet thickness. Parameters were varied to compare design options on the basis of NaK pump pressure rise and required power, heat pipe unit power and radial flux, radiator panel areal mass, and overall HRS mass.
\end{abstract}

\section{Introduction}

Nuclear Electric Propulsion (NEP) is a technology of current interest to because it has the potential to provide many benefits for deep space science missions including maneuverability to multiple mission targets, extended duration science, increased instrument power, and high data rate communications. The reactor power system reactor, power conversion, and heat rejection, is a critical element of the NEP spacecraft. Closed Brayton cycle (CBC) converters are one of several promising options for power conversion within an NEP system. The Heat Rejection Subsystem (HRS) must dissipate waste heat generated by the power conversion system due to inefficiencies in the thermal-to-electric conversion process. Brayton systems tend to optimize at efficiencies of about 20 to $25 \%$ with radiator temperatures in the 400 to $600 \mathrm{~K}$ range.

A previous design study examined a possible heat rejection concept for a $100 \mathrm{kWe}$ Brayton power system for the proposed Jupiter Icy Moons Orbiter (JIMO) mission. ${ }^{1}$ The power conversion included two (redundant) $100 \mathrm{kWe}$ Brayton converters. The heat rejection subsystem (HRS) consisted of a pumped sodium-potassium (NaK) heat transport loop coupled to a water heat pipe radiator as shown in Fig. 1 . The total radiator area was $170 \mathrm{~m}^{2}$ configured in two separate wings that extended radially from a central truss structure. The radiator panels provided two-sided heat rejection and were arranged in a "stair-case" configuration contained within a 10-degree cone halfangle as dictated by the conical reactor shield. Each radiator wing was dedicated to a single Brayton converter operating at $50 \%$ of rated power. Cross-strap NaK piping and a dual passage waste heat exchanger, allowed the full radiator (both wings) to serve a single Brayton converter operating at $100 \%$ power should a failure occur. The total mass of the HRS including radiator panels, pumps, plumbing, and deployment structure was reported as $854 \mathrm{~kg}$, or $5 \mathrm{~kg} / \mathrm{m}^{2}$ (based on total surface area). 


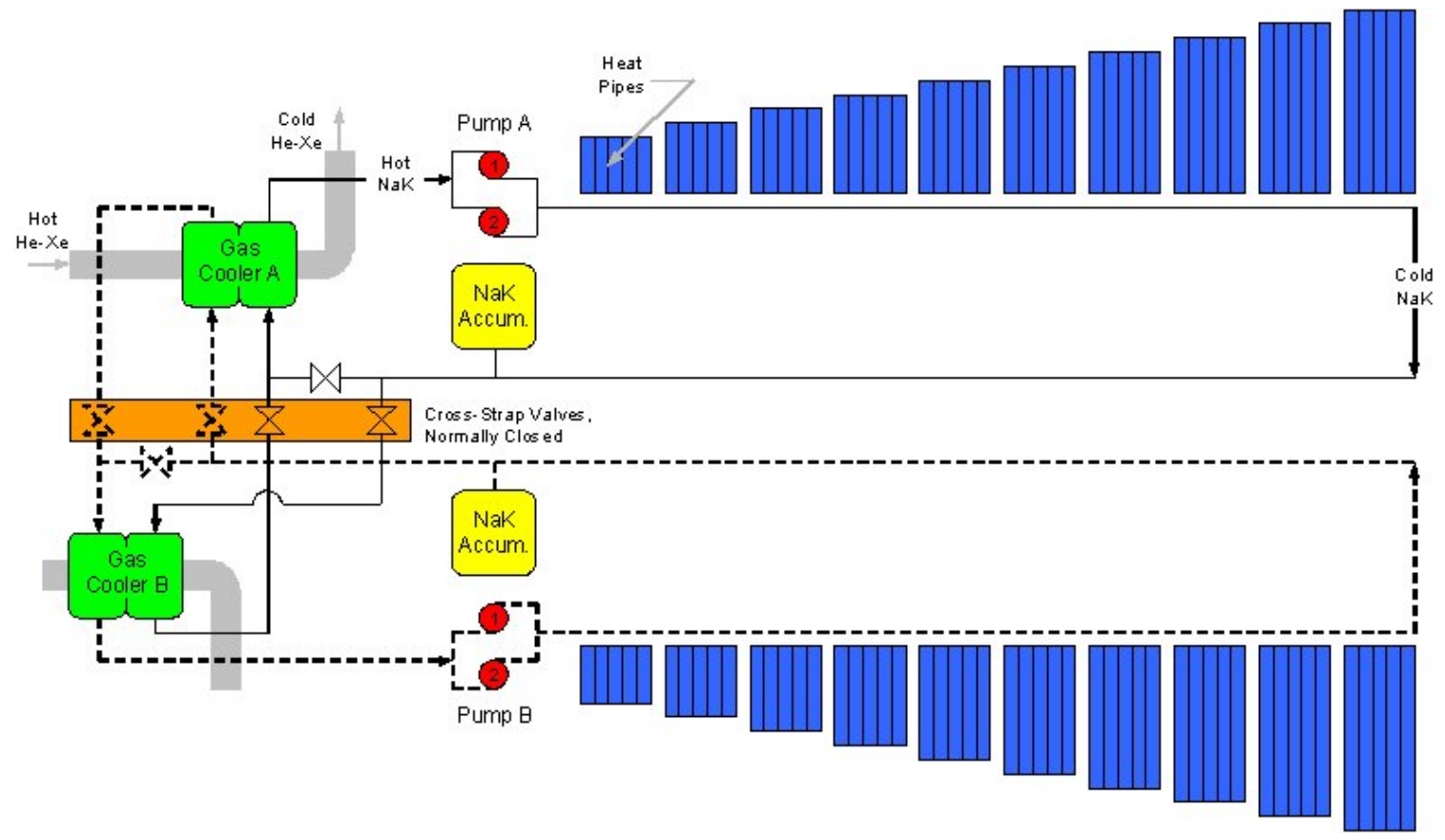

Figure 1. Brayton Heat Rejection Subsystem Schematic

This paper uses the previous design concept as a starting point for more rigorous definition of the Brayton HRS. Specifically, the paper evaluates various $\mathrm{NaK}$ heat transport and radiator panel design parameters.

\section{HRS Design Basis}

The HRS accepts heat from the Brayton power converters and rejects it into space through the radiator panels. A NaK cooling loop connects the Brayton converters to the radiator panels. The Brayton gas coolers serve as the thermal interface to the coolant loops. In the original Brayton HRS concept described in Ref. 1, there were two Brayton converters and two cross-strapped cooling loops. To improve the fault tolerance, the design has been modified to have four $50 \mathrm{kWe}$ Brayton converters, each having its own dedicated cooling loop. During nominal operation, only two of the four converters are used to produce the required $100 \mathrm{kWe}$. In the event of a Brayton converter failure or a heat transport loop failure, the backup systems are employed.

The radiator panels use a sandwich construction consisting of regularly-spaced circular heat pipes contained within two composite facesheets as shown in Fig. 2. The heat pipes use water as the working fluid and titanium containment. Heat pipes provide an efficient means of spreading the heat across the radiator surface with minimal temperature drop. The high conductivity composite facesheets serve as the radiator fin providing heat transfer between heat pipes. The heat pipes are thermally connected to the facesheets through a square saddle extending along the entire axial length of the heat pipe. A low density filler material is used between the heat pipes for panel structural integrity. The heat pipe-to-saddle and saddle-to-facesheet bond is accomplished through brazing or with a high temperature thermal adhesive. 


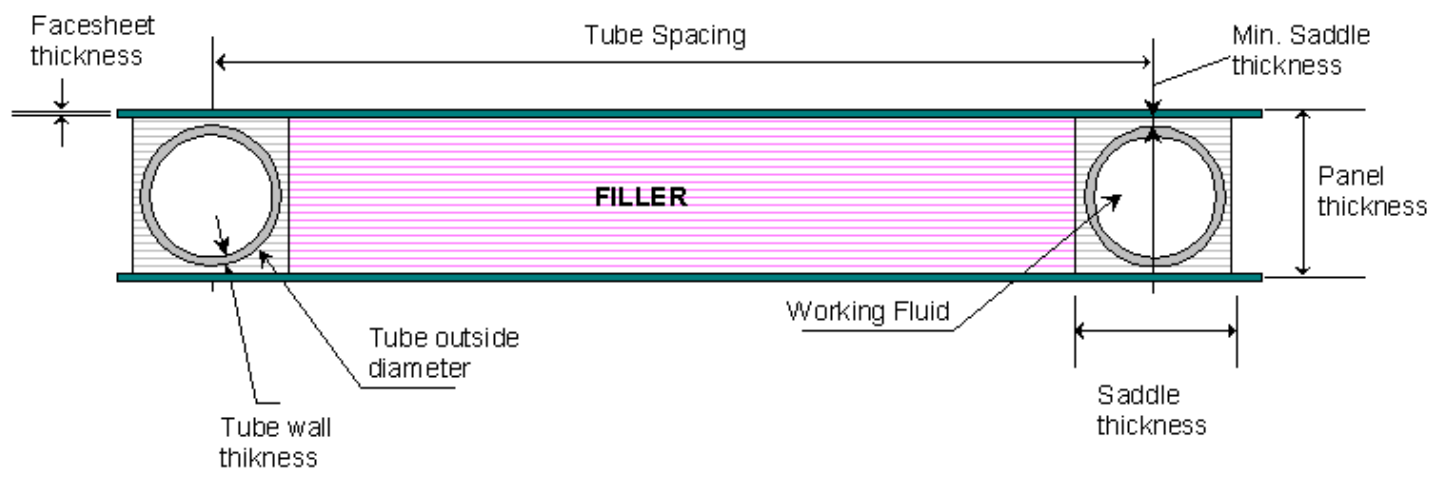

Figure 2. Radiator Panel Cross-Section

One of the key advantages to this type of radiator is its ability to withstand damage from micrometeoroid (MM) and orbital debris (OD). A fatal MM/OD impact to a single heat pipe, even though it will result in the failure of that heat pipe, would have minimal system performance impact.

The water heat pipes interface to the NaK coolant through embedded evaporator sections that are contained in the cooling loop as shown in Fig. 3. NaK provides a high specific heat coolant over a wide temperature band suitable to the Brayton cycle conditions. Alternative coolant options include hydrocarbons, fluorocarbons, organics, and water. The ducting is made of titanium with thin titanium sleeves that accept the heat pipe evaporators. The duct cross-section is square or rectangular. Each cooling loop includes an electromagnetic pump and a bellows accumulator.

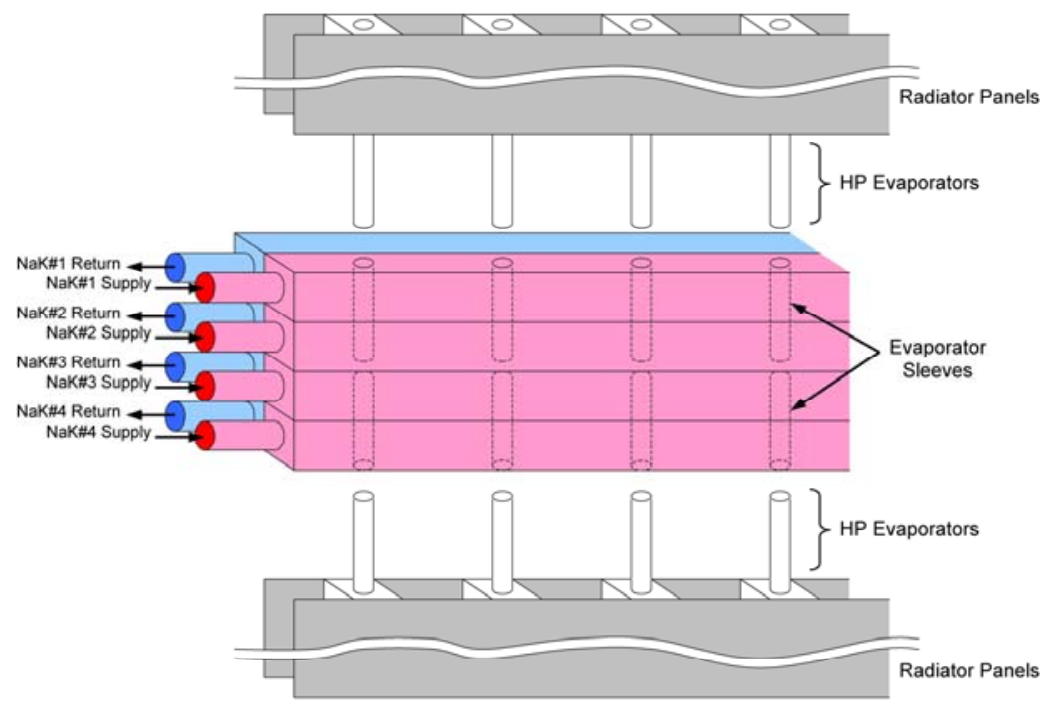

Figure 3. Heat Pipe Integration with NaK Cooling Loop 


\section{Analytical Model}

The design of the Brayton HRS depends on many parameters. Some of the critical design parameters include $\mathrm{NaK}$ duct size, heat pipe diameter, heat pipe spacing, and facesheet thickness. Many of these parameters are interrelated. For example, greater spacing between the heat pipes requires thicker facesheets to effectively transfer the heat. However, the reduced number of heat pipes results in fewer obstructions in the NaK cooling loop, reduced pressure drop and lower pumping power. The radiator panel areal mass may be better or worse depending if the heat pipe mass savings was greater or less than the facesheet mass increase. As one can see, there are many dependencies in selecting a good design.

A Microsoft ${ }^{\circledR}$ Excel spreadsheet model, called HRS-Opt, was developed to evaluate the design trade space. Parameters were varied to compare the design options on the basis of NaK pump pressure rise and required power, heat pipe unit power and radial flux, radiator panel areal mass, and overall HRS mass.

The fin efficiency is a critical part of this analysis since it varies widely with heat pipe spacing and facesheet thickness. A closed-form equation for fin efficiency was available in the literature ${ }^{2}$ and was adopted in HRS-Opt. In order to verify the accuracy of this equation and its applicability to the panel configuration, a detailed FiniteDifference model of a single heat pipe and half radiator fin was generated using SINDA. Figure 4 shows the details of the SINDA model indicating the number of nodes and the assumed geometry. The heat pipe spacing and fin thickness were varied and the results of the finite-difference model were compared to HRS-Opt. As Fig. 5 indicates, there was very good agreement between the HRS-Opt based fin efficiency calculations and the SINDA model results.

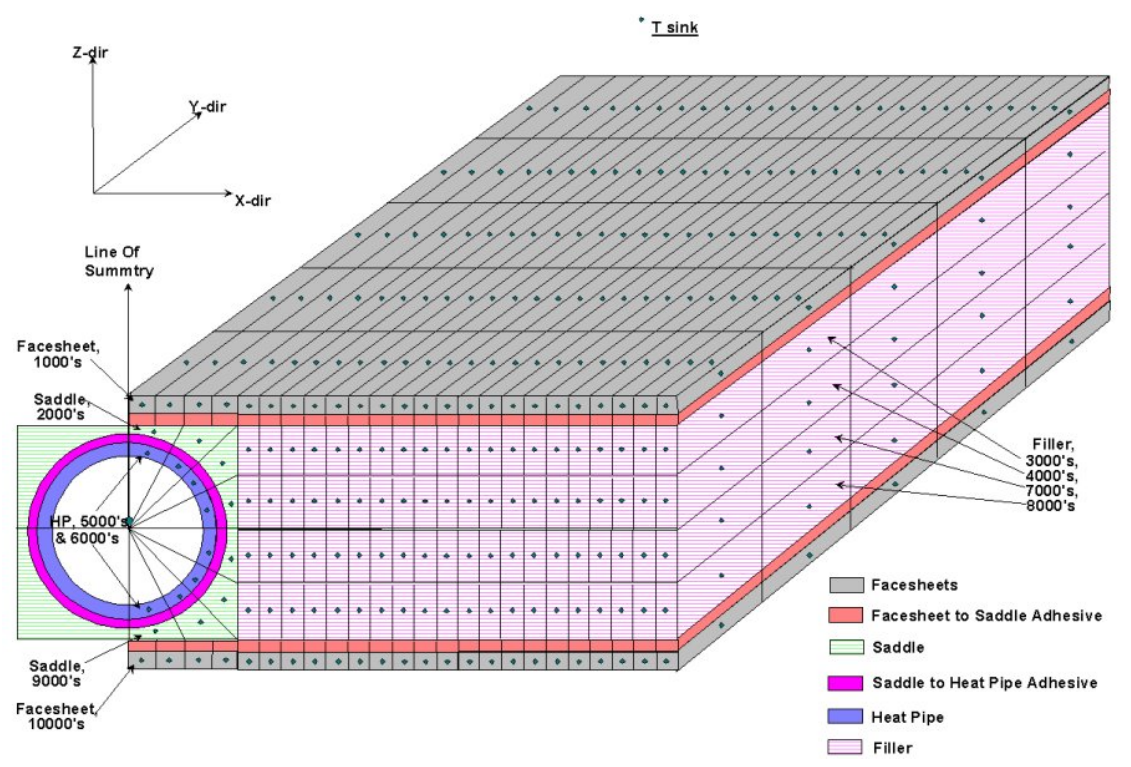

Figure 4. Heat Pipe and Radiator Fin SINDA Model 


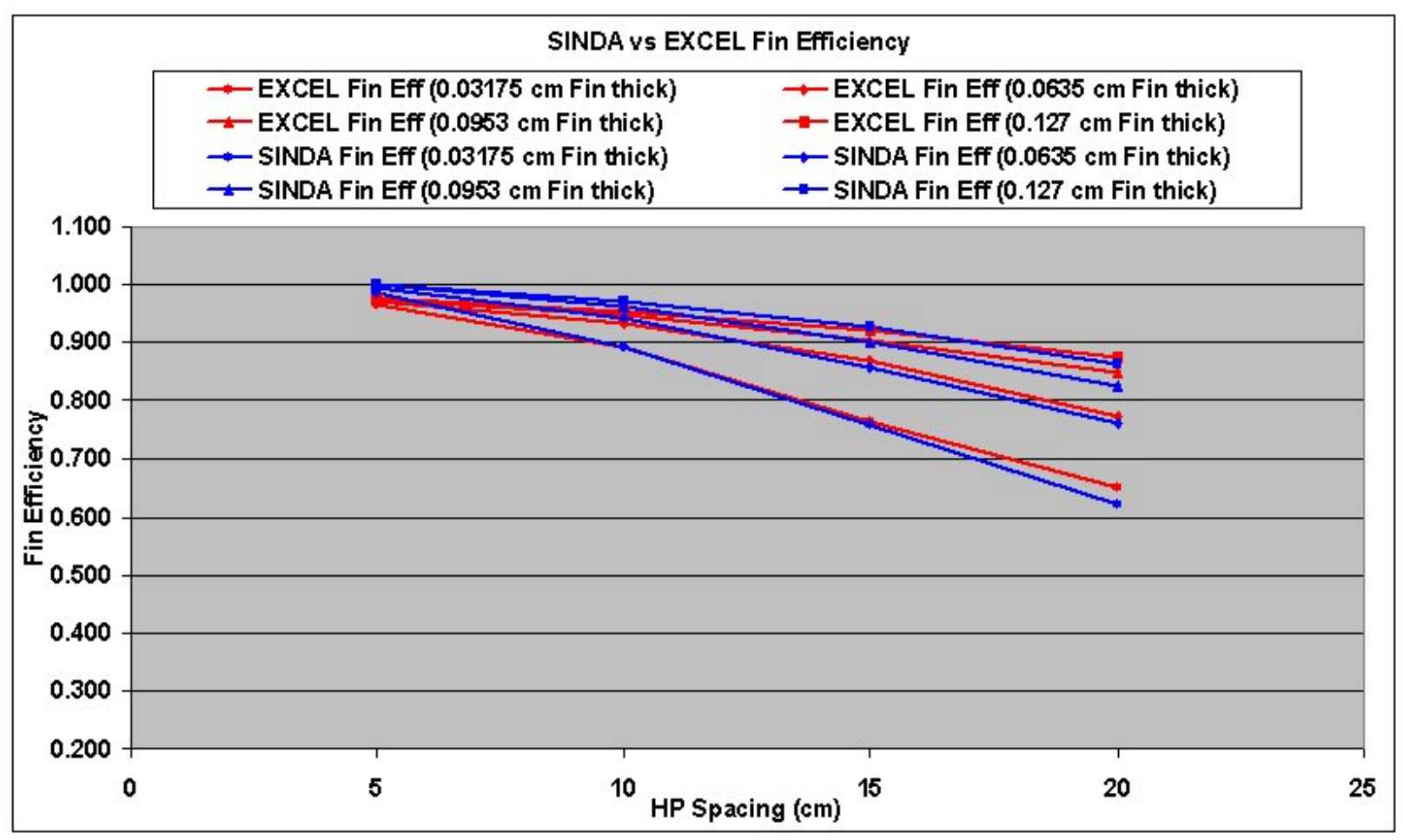

Figure 5. Comparison of HRS-Opt and SINDA Model Results

To estimate pressure drop in the $\mathrm{NaK}$ duct, the Computational Fluid Dynamics (CFD) code CFD Ace ${ }^{\mathrm{TM}}$, was used to model a one-meter long duct section. Numerous cases were modeled to generate a family of data points for pressure drop as a function of duct cross-section, heat pipe diameter, and heat pipe spacing within the duct. These data were used to develop a set of curve-fit equations for use in HRS-Opt to calculate the NaK pressure drop through the heat pipe section of the duct. The calculated pressure drop per meter was then scaled based on the length of the NaK supply duct. The calculated data points and the resulting curve-fit equations are shown in Fig. 6. The return duct pressure drop was also calculated using a conventional pressure drop analytical model from the literature. ${ }^{3}$ 


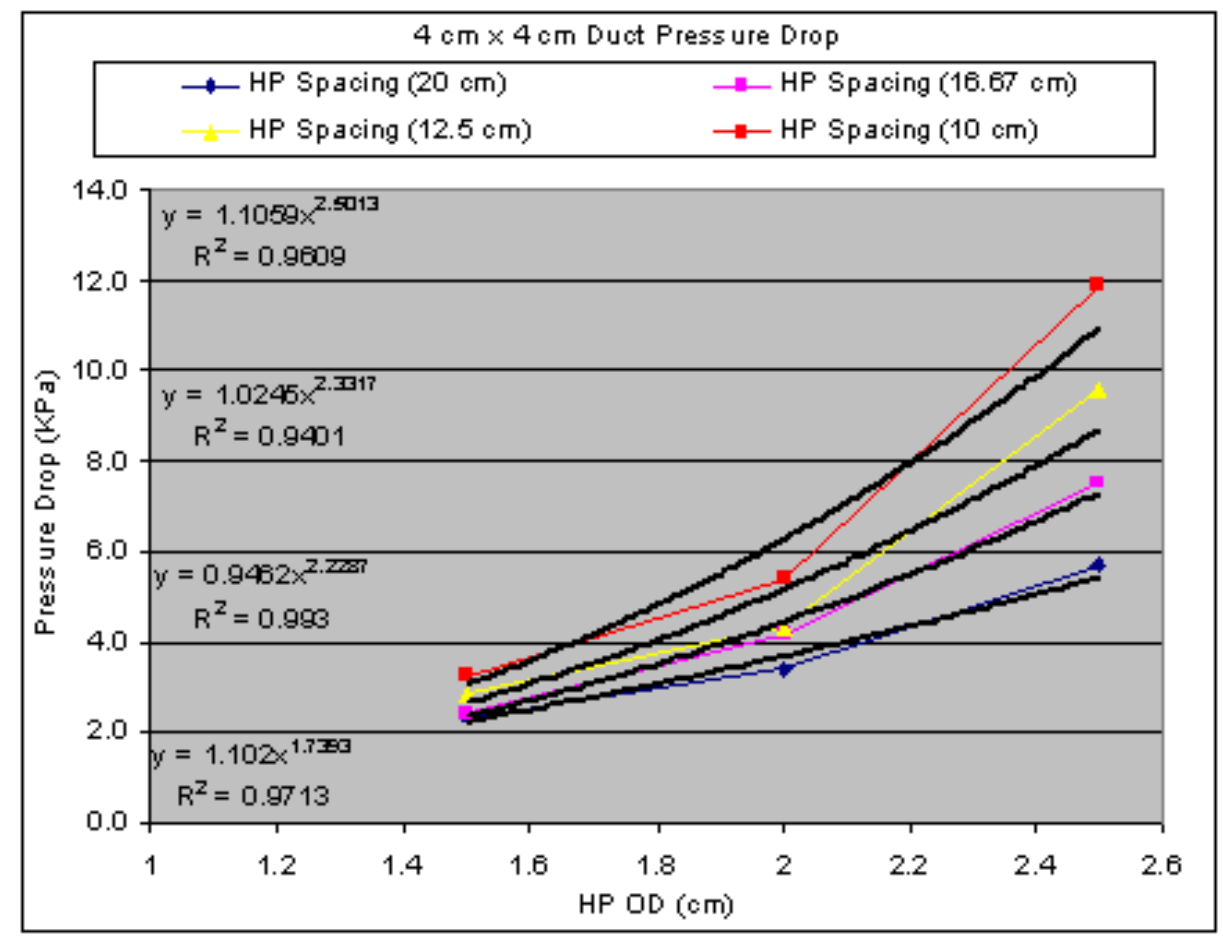

Figure 6. CFD Model Pressure Drop Results and Curve-Fits

\section{HRS Design Parameters}

The Brayton HRS described in Ref. 1 specified the primary thermal design requirements. The total radiator heat load was $364 \mathrm{kWt}$. The NaK radiator inlet temperature was $556 \mathrm{~K}$ and the radiator exit temperature was $399 \mathrm{~K}$. The $\mathrm{NaK}$ flow rate per operating loop was $1.28 \mathrm{~kg} / \mathrm{s}$ assuming $0.9 \mathrm{~kJ} / \mathrm{kg}-\mathrm{K}$ specific heat. The large temperature variation in the coolant results in a considerable span in the heat pipe operating conditions, given fixed heat pipe size and fin geometry. Heat pipes near the radiator inlet transfer much more heat than heat pipes near the exit due to their higher operating temperature. The NaK ducting was estimated to have a supply length of $25 \mathrm{~m}$ and a return length of $25 \mathrm{~m}$. The total radiator area was $170 \mathrm{~m}^{2}$ assuming 0.9 emissivity and a $200 \mathrm{~K}$ effective sink temperature. These thermal design requirements were held constant for this analysis.

Additional design details were needed before a substantive evaluation of the HRS trade space could be performed. This included a preliminary definition of construction materials and some of the dimensional parameters. For this study, these parameters were held constant, although the model allows them to be varied. The heat pipes were assumed to use water with a $10 \%$ liquid fill fraction. The assumed heat pipe containment was titanium $(4.5 \mathrm{~g} / \mathrm{cm} 3)$ with a $0.05 \mathrm{~cm}$ wall-thickness. The thermal saddles were assumed to be made of $0.54 \mathrm{~g} / \mathrm{cm} 3$ POCO $^{\mathrm{TM}}$ graphite with a $0.1 \mathrm{~cm}$ minimum thickness (where the heat pipe is closest to the facesheet). The assumed panel filler material was Reticulated Vitreous Carbon (RVC), with a density of $0.05 \mathrm{~g} / \mathrm{cm} 3$. The filler's thermal contribution to radiator fin heat transfer was negligible. The facesheets were carbon-carbon with a density of 1.92 $\mathrm{g} / \mathrm{cm} 3$ and thermal conductivity (normal to the direction of the heat pipes) of $600 \mathrm{~W} / \mathrm{m}-\mathrm{K}$.

The NaK duct channel was titanium with $0.05 \mathrm{~cm}$ wall-thickness and a $4 \mathrm{~cm}$ by $4 \mathrm{~cm}$ cross-section. The supply section of the ducting included sleeves to accommodate the heat pipe evaporator sections (the return duct section did not include sleeves). The evaporator sleeves were brazed into circular holes in the duct wall. The duct cross-section set the heat pipe evaporator length at $3.9 \mathrm{~cm}$. Since two NaK cooling loops had to interface with all the heat pipes associated with one radiator wing, two $3.9 \mathrm{~cm}$ evaporator sections were needed on every heat pipe. The evaporator sleeves were made of titanium and had a $0.01 \mathrm{~cm}$ wall-thickness with an inner diameter that matched the outer 
diameter of the heat pipe. A $1 \mathrm{~K}$ temperature drop was assumed between the NaK coolant and each heat pipe evaporator. The heat pipe condenser sections were assumed to be isothermal. The electromagnetic pump was assumed to have a pump efficiency of $15 \%$.

The primary design variables considered in this study were heat pipe spacing and heat pipe inner diameter. The range of parameters considered is provided in Table 1 . The four heat pipe spacing values corresponded to 10, 8, 6, and 5 heat pipes per meter of duct length. Given the four different spacing options and five heat pipe diameters, a total of twenty individual design cases were examined. The primary output parameters of interest included NaK pump pressure rise and required power, heat pipe unit power and radial flux, radiator panel areal mass, and total HRS mass. The total HRS mass includes the radiator panel mass, the heat transport mass with pumps and accumulators, and other hardware such as cross-strap valves, flexible fluid joints, and boom attachment hardware.

Table 1. Design Variables Used in Study

\begin{tabular}{|l|c|}
\hline \multicolumn{1}{|c|}{ Parameter } & Values Considered \\
\hline Heat Pipe Spacing & $10,12.5,16.67,20 \mathrm{~cm}$ \\
\hline Heat Pipe Inner Diameter & $1.5,1.75,2,2.25,2.5 \mathrm{~cm}$ \\
\hline
\end{tabular}

\section{Analytical Results}

For each case, the heat pipe spacing and the heat pipe inner diameter were given values. Then, the facesheet thickness was varied till the $\mathrm{NaK}$ radiator exit temperature reached the required value of $399 \mathrm{~K}$ and the radiator heat load matched the required value of $364 \mathrm{kWt}$. A sample case is reported in Table 2 for a $10 \mathrm{~cm}$ heat pipe spacing and a $1.5 \mathrm{~cm}$ heat pipe inner diameter. The resulting facesheet thickness required to achieve the $399 \mathrm{~K}$ radiator exit temperature was $0.47 \mathrm{~mm}$. The total panel thickness was $1.89 \mathrm{~cm}$, comprised of the $1.5 \mathrm{~cm}$ heat pipe ID, $0.05 \mathrm{~cm}$ (x2) heat pipe wall, $0.1 \mathrm{~cm}$ (x2) saddle, and $0.047 \mathrm{~cm}$ (x2) facesheet. The heat pipe geometry and facesheet thickness resulted in a fin efficiency of $90 \%$. The required pump pressure rise was calculated at $96 \mathrm{kPa}$ resulting in a pump power of 1960 watts. The maximum heat pipe power and radial flux was 1239 watts and $63.2 \mathrm{~W} / \mathrm{cm}^{2}$, respectively. The total HRS mass was $867 \mathrm{~kg}$ or $5.1 \mathrm{~kg} / \mathrm{m}^{2}$ (based on total surface area), and the radiator panel areal mass was $2.24 \mathrm{~kg} / \mathrm{m}^{2}$ (based on total surface area). 
Table 2. Sample Results Case

\begin{tabular}{|l|c|c|c|}
\hline Parameter & Units & Value & Basis \\
\hline Heat pipe spacing & $\mathrm{cm}$ & 10 & Input \\
\hline Heat pipe inner diameter & $\mathrm{cm}$ & 1.5 & Input \\
\hline Facesheet thickness & $\mathrm{mm}$ & 0.47 & Input \\
\hline Panel thickness & $\mathrm{cm}$ & 1.89 & Calculated \\
\hline Fin efficiency & $\mathrm{kPa}$ & $90 \%$ & Calculated \\
\hline Required pump pressure rise & watts & 96 & Calculated \\
\hline Total pump power & watts & 1960 & Calculated \\
\hline MAX heat pipe power & watts & 833 & Calculated \\
\hline AVE heat pipe power & $\mathrm{watts}$ & 370 & Calculated \\
\hline MIN heat pipe power & $\mathrm{W} / \mathrm{cm}^{2}$ & 63.2 & Calculated \\
\hline MAX heat pipe radial flux & $\mathrm{W} / \mathrm{cm}^{2}$ & 42.5 & Calculated \\
\hline AVE heat pipe radial flux & $\mathrm{W} / \mathrm{cm}^{2}$ & 18.9 & Calculated \\
\hline MIN heat pipe radial flux & $\mathrm{kg}$ & 404 & Calculated \\
\hline Total radiator panel mass & $\mathrm{kg}$ & 418.6 & Calculated \\
\hline $\begin{array}{l}\text { Total heat transport mass (with } \\
\text { pumps and accumulators) }\end{array}$ & $\mathrm{kg}$ & 44 & Calculated \\
\hline $\begin{array}{l}\text { Other hardware mass (valves, } \\
\text { flexible fluid joints, boom } \\
\text { attachment) }\end{array}$ & $\mathrm{kg}$ & 867 & Calculated \\
\hline Total HRS mass & $\mathrm{kg} / \mathrm{m}^{2}$ & 2.24 & Calculated \\
\hline Radiator panel areal mass & $\mathrm{kg} / \mathrm{m}^{2}$ & 5.1 & Calculated \\
\hline Total HRS areal mass & & & \\
\hline
\end{tabular}

Figure 7 shows the variance of the radiator facesheet thickness as a function of heat pipe spacing. Results show that as the heat pipe spacing increases, thicker facesheet is needed to reject the required amount of heat into space. Heat pipe spacing has an effect on the overall fin efficiency. As the heat pipe spacing increases, the overall fin efficiency decreases and thicker facesheet is therefore required to make up for the lost efficiency.

Figure 8 shows the variance of the radiator panel thickness as a function of heat pipe spacing and heat pipe diameter. For a given heat pipe diameter, an increase in spacing results in a thicker panel due to thicker face sheets needed to maintain overall heat rejection for a fixed radiator area. The figure also shows the obvious effect of a larger diameter heat pipe resulting in a thicker panel.

Figure 9 shows the variance of the radiator panel areal mass as a function of heat pipe spacing and heat pipe diameter. Results show that as the heat pipe spacing increases, the radiator panel areal mass also increases, due to the fact that the radiator panel areal mass just follows the variance of the total radiator panel mass as a function of heat pipe spacing. For the same reason, the effect of the heat pipe diameter is greater at low heat pipe spacing.

Figure 10 shows the variance of the total HRS mass as a function of heat pipe spacing and heat pipe diameter. Results show that as the heat pipe spacing increases, the total radiator panel mass also increases since (as seen earlier), thicker facesheet and radiator panels are needed to reject the required amount of heat into space, and that the effect of the heat pipe diameter is greater at low heat pipe spacing due to relative pumping efficiencies (and thus pump masses) for the different configurations.

Figure 11 shows the variance of the heat pipe maximum heat flux as a function of heat pipe spacing and heat pipe diameter. Results show that as the heat pipe spacing increases, the maximum heat flux required of a heat pipe also increases. This is due to the fact that as the heat pipe spacing increases, the total number of heat pipes decreases, while the total energy to be rejected by the radiator remains constant. Results also show that as the heat pipe diameter increases, the heat pipe maximum heat flux decreases since a larger diameter heat pipe has more evaporator area. 
Figure 12 shows the variance of the heat pipe power as a function of heat pipe spacing and heat pipe diameter. Required heat pipe power increases with increased spacing for the same reasons as discussed above for heat pipe flux

Figure 13 shows the variance of the heat pipe area exposed to MMOD as a function of heat pipe spacing and heat pipe diameter. Results show that as the heat pipe spacing increases, the heat pipe area exposed to MMOD decreases, due to fewer heat pipes. Results also show that as the heat pipe diameter decreases, the heat pipe area exposed to MMOD decreases

Figure 14 shows the variance of the total pump pressure drop as a function of heat pipe spacing and heat pipe diameter. Results show that as the heat pipe spacing decreases, the total pump pressure drop increases, due to the fact that as the heat pipe spacing decreases, the total number of heat pipes increases, which therefore increases the total pump pressure drop. Results also show that as the heat pipe diameter increases, the total pump pressure drop increases, due to the fact that as the heat pipe diameter decreases, the fluid cross sectional flow area decreases which increases total pump pressure drop.

Figure 15 shows the variance of the total pump power as a function of heat pipe spacing and heat pipe diameter. The results show that as heat pipe spacing decreases, the total pump power increases, due to the greater number of heat pipes per meter of duct. Results also show that as the heat pipe diameter increases, the total pump power increases, due to the reduced fluid cross sectional flow area and resultant increase in pressure drop.

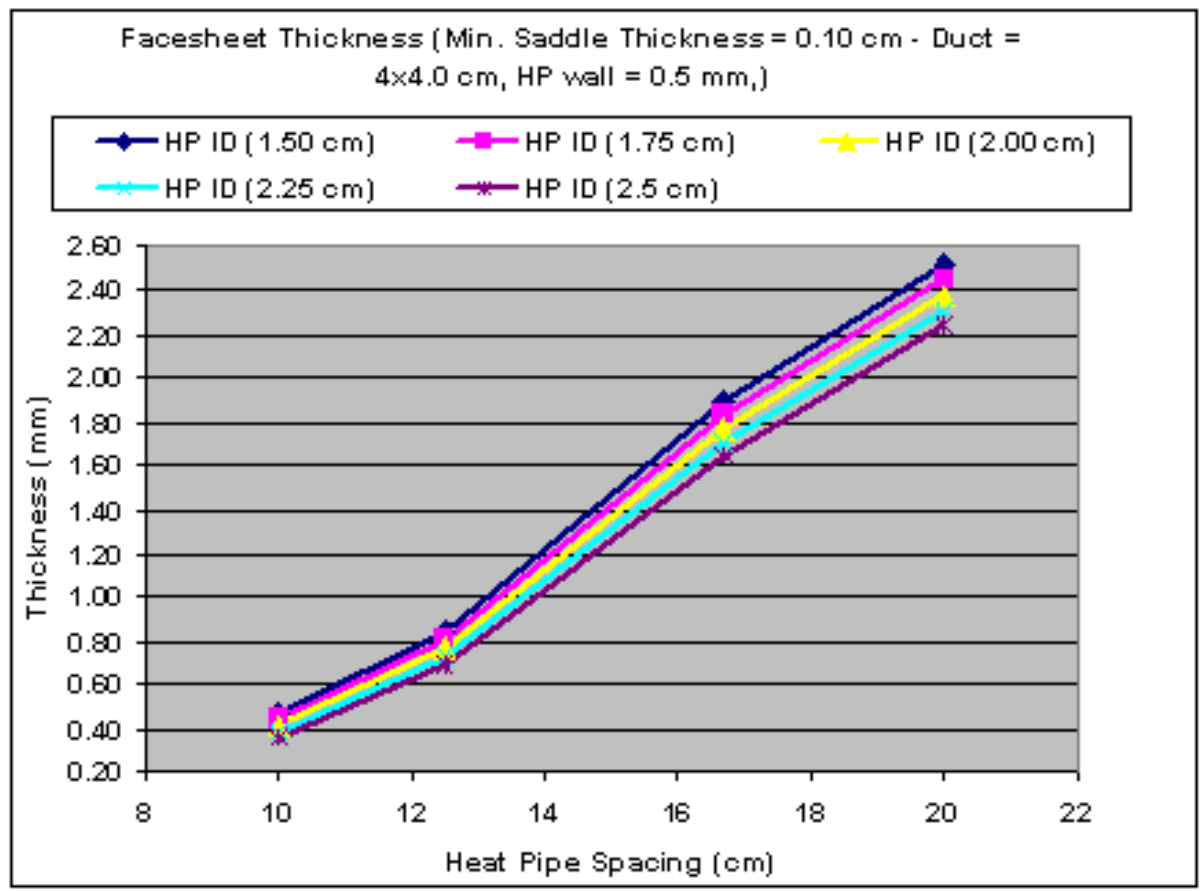

Figure 7. Facesheet Thickness versus Heat Pipe Spacing and Inner Diameter 


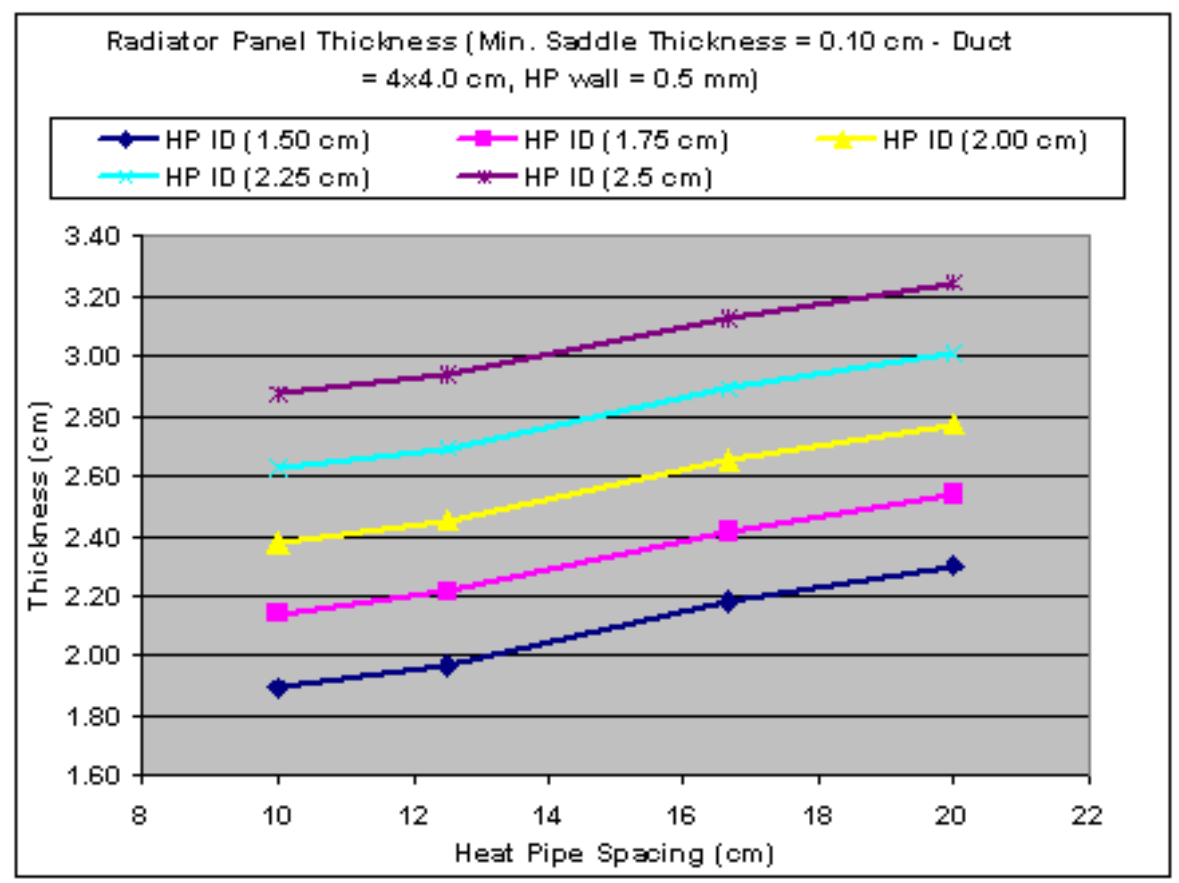

Figure 8. Radiator Panel Thickness versus Heat Pipe Spacing and Inner Diameter

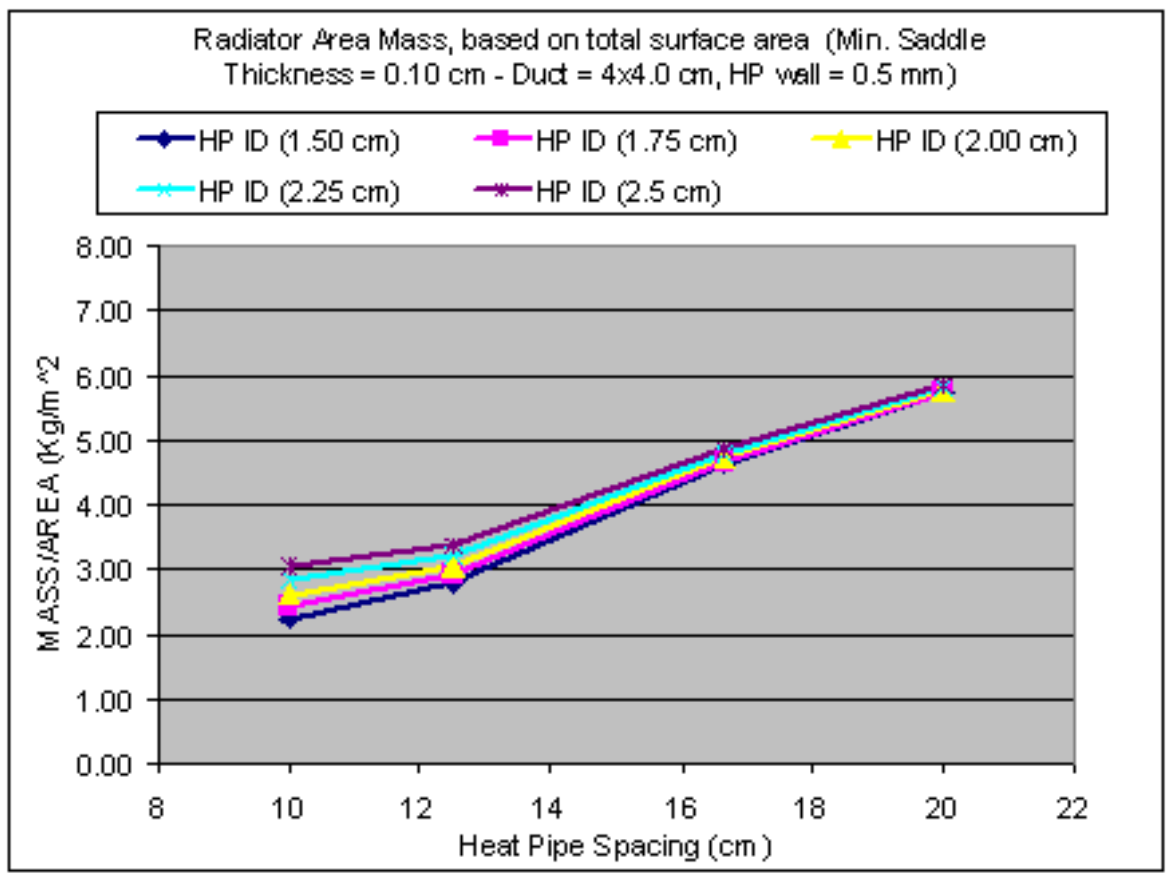

Figure 9. Radiator Panel Areal Mass versus Heat Pipe Spacing and Inner Diameter 


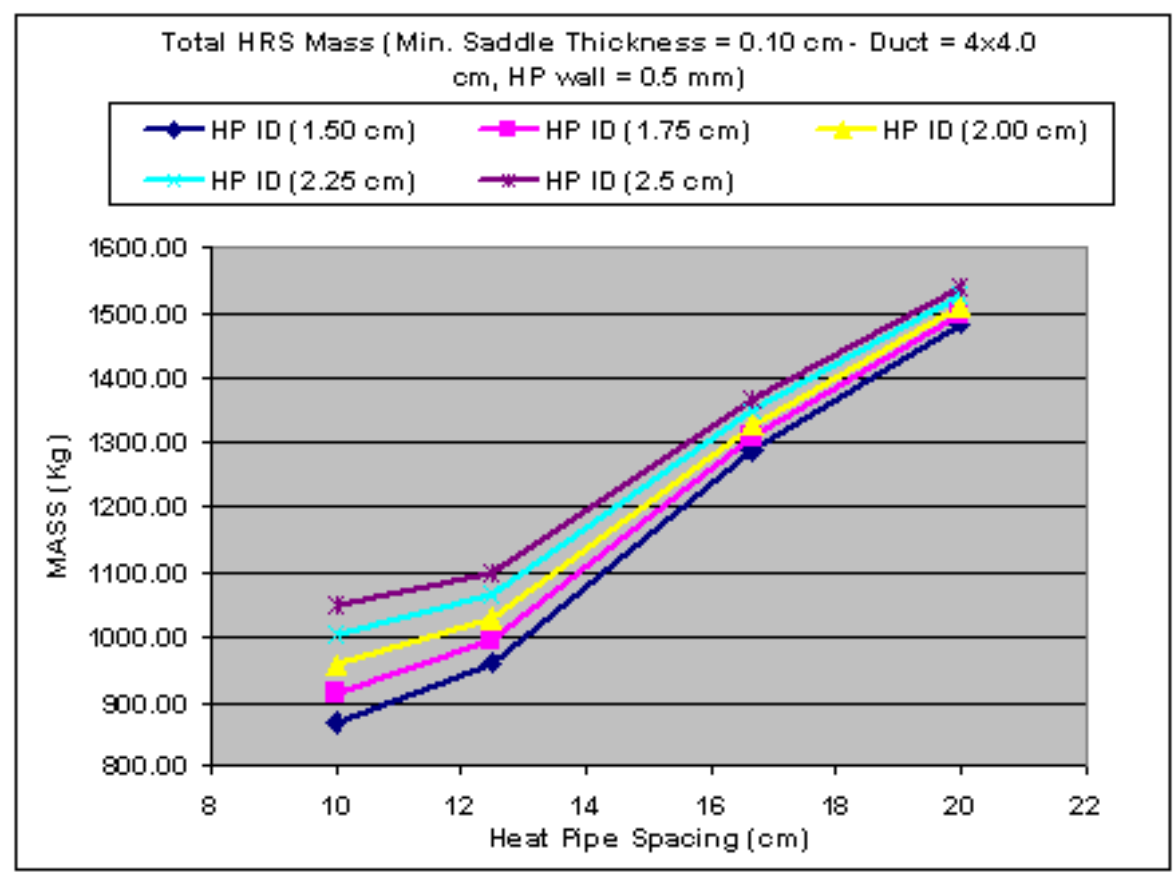

Figure 10. Total HRS Mass versus Heat Pipe Spacing and Inner Diameter

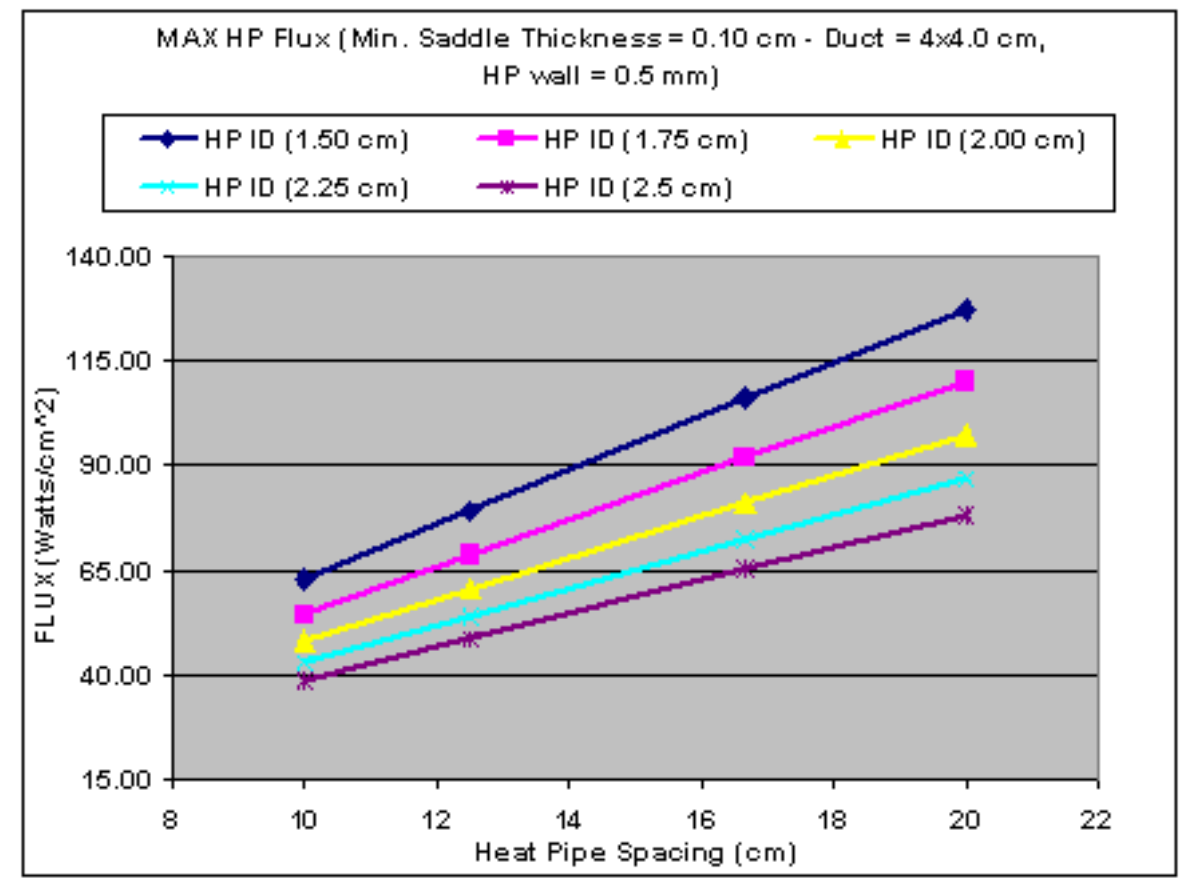

Figure 11. Maximum Heat Pipe Radial Flux versus Heat Pipe Spacing and Inner Diameter 


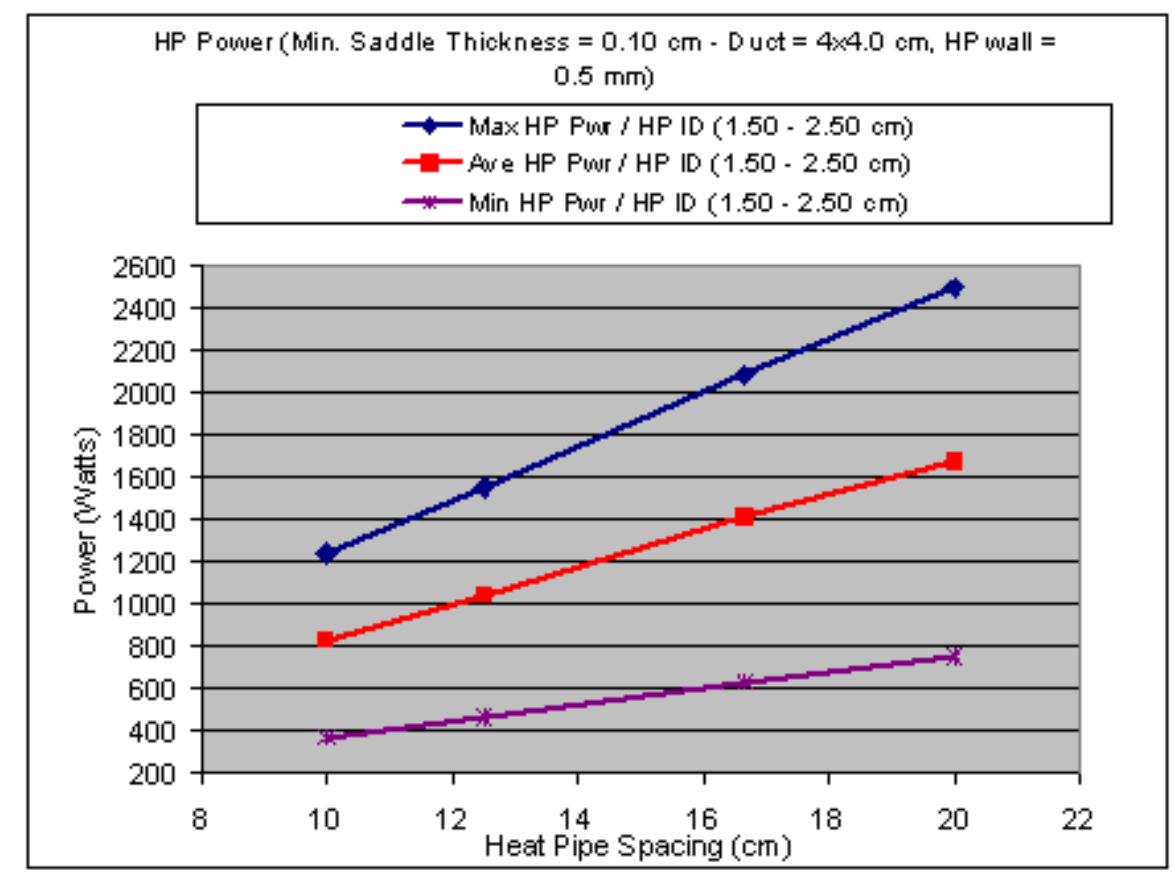

Figure 12. Maximum Heat Pipe Power versus Heat Pipe Spacing and Inner Diameter

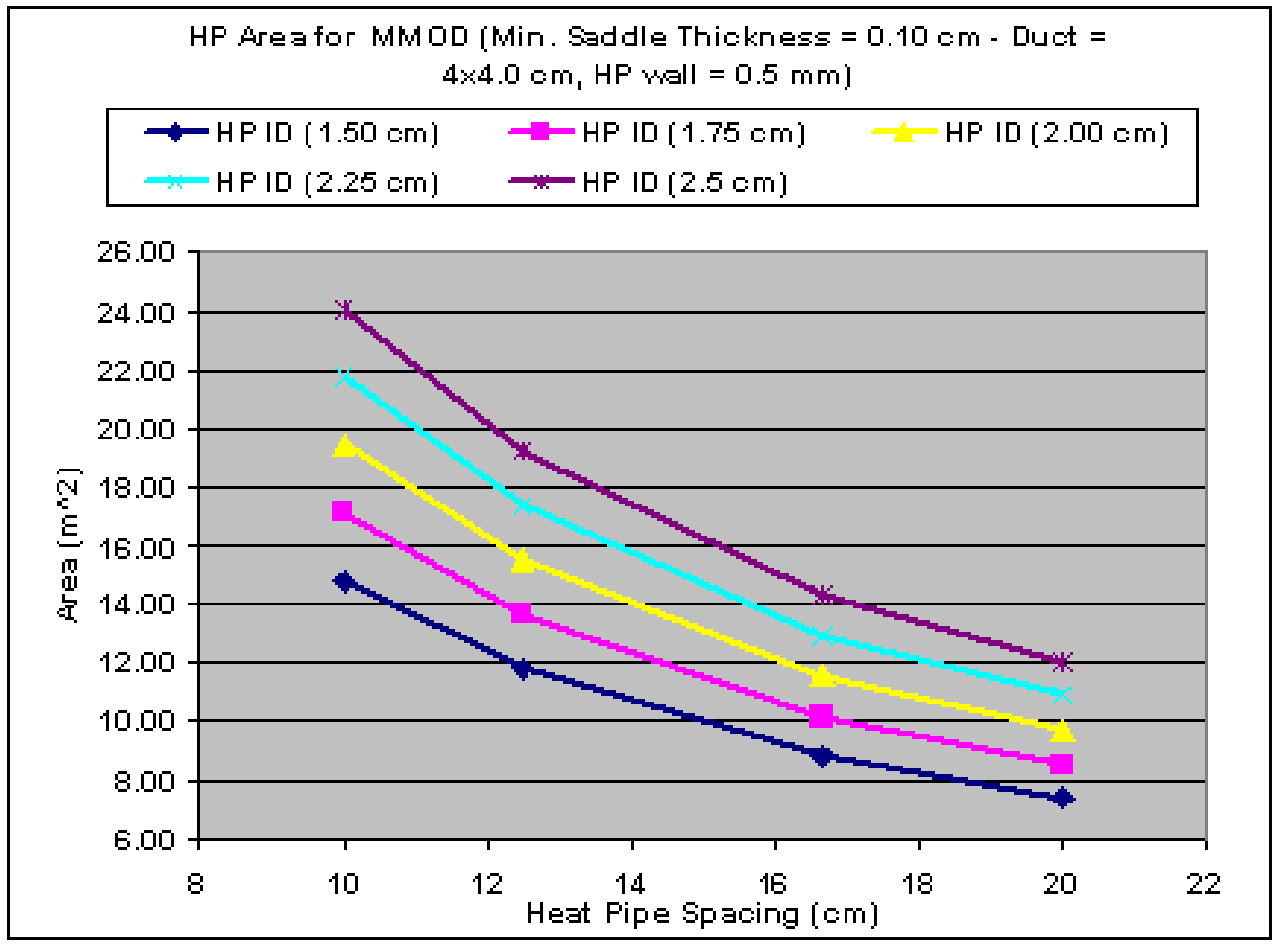

Figure 13. Vulnerable MMOD Area versus Heat Pipe Spacing and Inner Diameter 


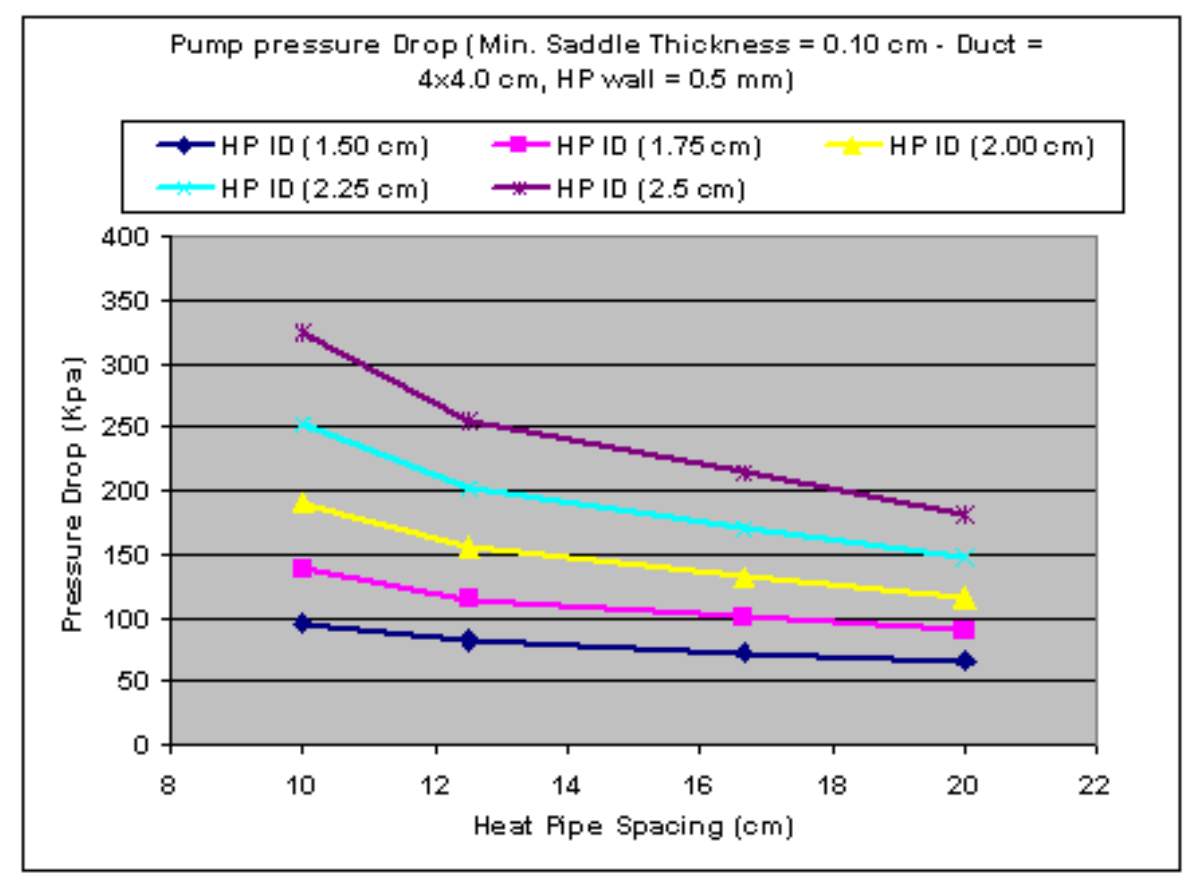

Figure 14. System Pressure Drop versus Heat Pipe Spacing and Inner Diameter

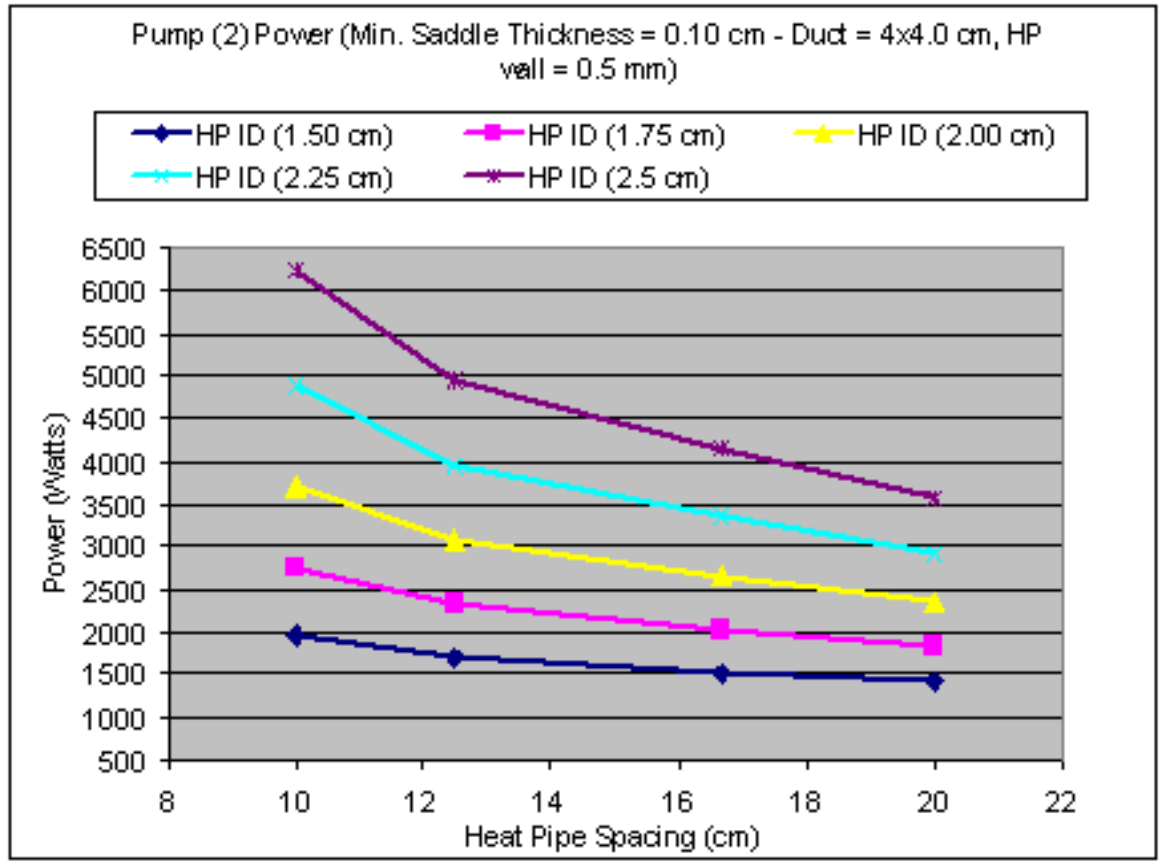

Figure 15. Pump Power versus Heat Pipe Spacing 


\section{Conclusion}

Earlier HRS design trades were conducted addressing heat transport approaches, material and fluid options, and deployed radiator geometries. This paper discussed the interplay between heat pipe spacing and diameter and their effect on heat pipe maximum heat flux, maximum heat pipe power, heat pipe area exposed to MMOD, pump pressure drop and pump power for a fixed geometry radiator.

Based on the results of this paper, the sample results case shown in Table 2 gives us the lowest mass HRS of all cases analyzed given the requirements specified for total radiator area and heat load. The total HRS mass was 866.6 $\mathrm{kg}$ or $5.1 \mathrm{~kg} / \mathrm{m}^{2}$ (based on total surface area). These results are in very good agreement with the results of the previous design study (Ref. 1), which indicated an HRS mass of $854 \mathrm{~kg}$ or $5.0 \mathrm{~kg} / \mathrm{m}^{2}$ (based on total surface area).

Additional trade studies are needed to further refine the HRS design. These studies would compare heat pipe maximum heat flux and maximum power requirements with actual heat pipe capabilities. This could present constraints on heat pipe size and spacing that were not considered in this study. Another potential variation on the study is the possibility of segmenting the radiator based on temperature. Heat pipe diameter and spacing could be tailored based on panel operating temperatures. The higher temperature sections of the radiator panels could use larger heat pipes with reduced spacing, while the coolers sections could use smaller heat pipes with greater spacing. This approach could provide mass savings while reducing the maximum power and flux for the high temperature heat pipes.

\section{References}

\footnotetext{
${ }^{1}$ Mason, L.S., “A Power Conversion Concept for the Jupiter Icy Moons Orbiter,” NASA/TM-2003-212596, 2003.

${ }^{2}$ Gilmore, D.G., "Satellite Thermal Control Handbook,” The Aerospace Corporation Press, El Segundo, California, 1994.

${ }^{3}$ White, Frank M., “Fluid Mechanics,” McGraw-Hill, December 2002.
} 
Public reporting burden for this collection of information is estimated to average 1 hour per response, including the time for reviewing instructions, searching existing data sources, gathering and maintaining the data needed, and completing and reviewing the collection of information. Send comments regarding this burden estimate or any other aspect of this
collection of information, including suggestions for reducing this burden, to Washington Headquarters Services, Directorate for Information Operations and Reports, 1215 Jefferson Davis Highway, Suite 1204, Arlington, VA 22202-4302, and to the Office of Management and Budget, Paperwork Reduction Project (0704-0188), Washington, DC 20503.

\begin{tabular}{|l|l|l}
\hline 1. AGENCY USE ONLY (Leave blank) & $\begin{array}{c}\text { 2. REPORT DATE } \\
\text { March } 2005\end{array}$ & $\begin{array}{r}\text { 3. REPORT TYPE AND DATES COVERED } \\
\text { Technical Memorandum }\end{array}$
\end{tabular}

\section{TITLE AND SUBTITLE} 5. FUNDING NUMBERS

Heat Rejection Concepts for Brayton Power Conversion Systems

6. $\operatorname{AUTHOR(S)}$

WBS-22-973-80-40

John Siamidis, Lee Mason, Duane Beach, and James Yuko

7. PERFORMING ORGANIZATION NAME(S) AND ADDRESS(ES)

National Aeronautics and Space Administration

John H. Glenn Research Center at Lewis Field

Cleveland, Ohio 44135-3191

8. PERFORMING ORGANIZATION REPORT NUMBER

E-14807

\section{SPONSORING/MONITORING AGENCY NAME(S) AND ADDRESS(ES)}

National Aeronautics and Space Administration

Washington, DC 20546-0001

10. SPONSORING/MONITORING AGENCY REPORT NUMBER

NASA TM-2005-213337

AIAA-2004-5654

\section{SUPPLEMENTARY NOTES}

Prepared for the Second International Energy Conversion Engineering Conference sponsored by the American Institute of Aeronautics and Astronautics, Providence, Rhode Island, August 16-19, 2004. John Siamidis, Analex Corporation, Brook Park, Ohio 44142; and Lee Mason, Duane Beach, and James Yuko, NASA Glenn Research Center. Responsible person, John Siamidis, organization code RPT, 216-433-3151.

12a. DISTRIBUTION/AVAILABILITY STATEMENT 12b. DISTRIBUTION CODE

Unclassified - Unlimited

Subject Category: 20

Distribution: Nonstandard

Available electronically at http://gltrs.grc.nasa.gov

This publication is available from the NASA Center for AeroSpace Information, 301-621-0390.

13. ABSTRACT (Maximum 200 words)

This paper describes potential heat rejection design concepts for closed Brayton cycle (CBC) power conversion systems. Brayton conversion systems are currently under study by NASA for Nuclear Electric Propulsion (NEP) applications. The Heat Rejection Subsystem (HRS) must dissipate waste heat generated by the power conversion system due to inefficiencies in the thermal-to-electric conversion process. Space Brayton conversion system designs tend to optimize at efficiencies of about 20 to 25 percent with radiator temperatures in the 400 to $600 \mathrm{~K}$ range. A notional HRS was developed for a $100 \mathrm{kWe}-c l a s s$ Brayton power system that uses a pumped sodium-potassium (NaK) heat transport loop coupled to a water heat pipe radiator. The radiator panels employ a sandwich construction consisting of regularly-spaced circular heat pipes contained within two composite facesheets. Heat transfer from the NaK fluid to the heat pipes is accomplished by inserting the evaporator sections into the NaK duct channel. The paper evaluates various design parameters including heat pipe diameter, heat pipe spacing, and facesheet thickness. Parameters were varied to compare design options on the basis of $\mathrm{NaK}$ pump pressure rise and required power, heat pipe unit power and radial flux, radiator panel areal mass, and overall HRS mass.

14. SUBJECT TERMS

15. NUMBER OF PAGES

Heat rejection; Radiator; Brayton power conversion; Heat pipes 20

\begin{tabular}{|c|c|c|}
\hline $\begin{array}{c}\text { 17. SECURITY CLASSIFICATION } \\
\text { OF REPORT } \\
\text { Unclassified }\end{array}$ & $\begin{array}{c}\text { 18. SECURITY CLASSIFICATION } \\
\text { OF THIS PAGE } \\
\text { Unclassified }\end{array}$ & $\begin{array}{c}\text { 19. SECURITY CLASSIFICATION } \\
\text { OF ABSTRACT } \\
\text { Unclassified }\end{array}$ \\
\hline
\end{tabular}

NSN 7540-01-280-5500

Standard Form 298 (Rev. 2-89) 

